\title{
THE ROLES OF ACADEMIC ADVISOR TO THE LEARNING MOTIVATION OF THE SEVENTH SEMESTER STUDENTS' OF ENGLISH EDUCATION AT ALAUDDIN STATE ISLAMIC UNIVERSITY OF MAKASSAR
}

\author{
Ahmiranil Khairat \\ English Education Department of UIN Alauddin Makassar \\ abmiranilkbaerat@gmail.com
}

\begin{abstract}
The objective of this research was to find out the result of the roles of academic advisor to the students learning motivation at the seventh semester students of English Education Department of UINAM. This research was quantitative descriptive by doing survey and conducted at the seventh semester students of English Education Department group 3 and 4 Tarbiyah and Teaching Science Faculty UIN Alauddin in academic year 2014/2015. The total sample of this research consisted of 36 students. This research is conducted by using quantitative approach, the data were collected through questionnaire and descriptive analysis as the data analysis method. The questionnaire was divided into two types, students' learning motivation questionnaire and the roles of academic advisors. The data analysis and interpretation indicated: (1) There was a medium category from the roles of academic advisors (2) There was a medium category from the students learning motivation. (3) There was a significant relationship between the roles of academic advisors to the students learning motivation. In brief, it could be concluded that there is a significant relationship between the roles of academic advisor to the students learning motivation.
\end{abstract}

KEY WORDS: roles of academic advisor, academic advisor, learning motivation.

\section{A. INTRODUCTION}

urrently, education gives a huge effect to the human life. It has an
important role to guarantee an enhancement and the continuity of people
in their entire life. Education is one of those tools that serve the need of wise, efficient and effective management resources. Ahmad D. Marimba in (Hasbullah, 2009: 3) portrayed that education is the guidance which is consciously led by the educator to the development of physical and spiritual formation from the students to build their main personality.

Principally, education bears for molding a well-prepared student for the future like what had been writing at Undang-Undang National Education System 
Ahmiranil Khairat, The Roles of Academic Advisor To The Learming Motivation ...

2003 (UUD, 2010: 3) national education is a tool of increasing the capability and the golden character of the students that educate them to be a high qualified students who have a superior character. Moreover, to fulfill national education goals, government policy begs to all university to intensify the quality of university. This brings about every university should compete to be a high quality and a high qualified university.

Year by year, every university must escalate the pearl principle academic quality based on the progress and the development of academic knowledge that is being on the top of the session. Hence, the output quality of the university can compete not only in achieving knowledge but also in creating a job. From this case, public university should provide some particular educators to help the students in reaching the entirety of their academic career. But, particular educators also give them such as guidance, mind mapping, and motivation to fulfill their vision in learning process. These particular educators called academic advisor. Kevin D. Egan stated that the relationship between academic advisor and the student are like "bigh touch" interaction (Egan, 2014:3). It means that the philosophical characteristic of empowering students is to design their own curricula in their academic plan. Broadly, this program enables students to draw their innovative connection across the field of their knowledge.

Guidance, motivation, and an advice should be boosted to the students. With the result, they can attain a wide range of ability, good personality, and exploring a bunch of knowledge. According to the professional advisor, ("The Provost University of Pittsburgh", 2014) stated that the quality of education which graduates students is greatly enhanced if the students receive a good academic advice at all stages of their study program. Students need a good advising when they are recruited, when they are in the first register at later stages in the program, when they graduate and when they look for a job. Their advice depends on the type of program they are pursuing.

Alauddin State Islamic University of Makassar as one of the higher national education always makes a new breakthrough to actualize the principle of national education. Hence, as an object and subject in the university, the students and the lecturers involve directly to the learning and teaching process in the university. The successful learning and teaching process is determined from the partnership between the students and the lecturers. Otherwise, they have to work together, conduct, and support a bunch of activities that relate to the students' academic program.

Thus, learning development never separates from the learning motivation. One of the things that academic advisors should do is designing, building, and 
molding a learning motivation to the students. In fact, there was relationship between academic advisor and students' motivation. That proves from how much time they spend to do academic advice. Whereas, the more a student and her or his advisor discuss personal about his or her school-related issues, career options, academic deadline, the higher learning motivation they achieve. (Pargett, 2011: 9) mentioned on his thesis the more likely the positively students can establish a higher level of motivation for running of their daily academic life.

As the first assumption of the researcher, this phenomenon is not occurring in English Education Department. From some informal and unstructured interviews, the researcher found that most of the students in English Education Department never feel academic advising activities like normal from academic advisor. In reality, academic advisors only give a service oriented towards the provision of KRS endorsement as the first important beginner to the students that must require it in the beginning of each semester. It means that academic advisor only give a signature without knowing everything happened to their students. No dialog, no discussion, and no motivation to their advisee.

From this proponent the researcher is awfully interested to improve the quality of academic process and academic product of the students in Alauddin State Islamic University of Makassar, especially in English Education Department students by looking at the roles of academic advisors to the student learning motivation.

\section{B. LITERATURE REVIEW}

A number of studies had been conducted in order to investigate the roles of academic advisor to the students' learning motivation. First, According to Aksan (2010) in his research about "Hubungan Kinerja Penasehat Akademik Dengan Motivasi Belajar di Jurusan Pendidikan Biologi Fakultas Tarbiyah dan Keguruan Universitas Islam Negeri Makassar", there are only few impressions from academic advisor to the students' learning motivation, it was supported by the evidence that the result of the data, there $14,44 \%$ the influence of the roles of academic advisor to the students' learning motivation. it means that the roles of academic advisor to the students' learning motivation is working well. Tri Sunarsih (2009) in her research about "Hubungan Antara Motivasi Belajar, Kemandirian Belajar, dan Bimbingan Akademik Terbadap Prestasi Pelajar Mahasiswa di STIKES A.Yani Yogyakarta” implies that in achieving students' learning target must be bound to the students' motivation. From this term students' learning motivation is established from academic advisor.

Furthermore, Pargett (2011) in his theses about "The Effects of Academic Advising on College Student Development in Higher Education", she found that every faculty 
has a significant impact on student development of higher education. Developing a professional relationship between student and academic advisor has significant benefits not only for student development, but overall student satisfaction and motivation as well.

Besides, NurHasyim and Hafiuddin (2010) in their thesis about "Peran Pembimbing Akademike Dalam Mengoptimalkan Hasil Studi Mahasiswa: Studi Pada Politeknik Negeri Jakarta" found that the roles of academic advisor is more essential in achieving students' learning achievement. The successful of the students can be occurred by the encouragement from the academic advisor. The higher motivation from the academic advisor the sooner the students gain their target of knowledge.

It can be concluded that the roles of academic advisor can mold a huge impact to the students' learning motivation.

This section presented the roles of academic advisor to the students' learning motivation.

\section{The definition of academic advisor}

Academic advisor is a lectures who already have functional positions in the faculty assigned to carry out the academic guidance. Academic guidance is all the activities that are implemented by the Academic Advisor in the effort to bring the provisions of applicable to achieve the academic target relate to the students circumstances. (Pedoman Edukasi UIN Makassar, 2010: 59)

The American Association of Collegiate Registrars and Admissions Officers cited in (Jerry Ford, 2014: 6) has stated that an advisor is a member of the college staff, usually a member of the instructional faculty assigned to assist student with academic planning. Crocket contends that the faculty advisor serves as a coordinator of the advisee's educational experiences (Crocket,1978: 52). It means that the advisor needs ability to help students define and develop realistic goals, to perceive their needs accurately, and to match these needs with appropriate institutional resources.

\section{The Roles of Academic Advisors}

According to (Panduan Edukasi UIN Makassar, 2013:59) academic advisor have many duties they are involving in: firstly, Academic advisors give such a advice and guidance to the students for helping their study. Secondly, academic advisors bestow a direction to the students in selecting their course and assigning students to determine the score of their academic that they have been chosen every first semester appropriately based on the particular stipulation.

Thirdly, Academic advisors always check with the chief of academic section (KASUBAG) related to the students' academic program. Fourthly, academic advisors 
are able to give such as consideration to the headmaster of the major/dean of faculty about the students' academic program. It means that every single academic activity that the students concern about must be known by the dean of the faculty as their consideration. Fifthly, Academic advisors follow the development study of their students and help them deal with the difficulty that relates to their study. Sixtbly, Academic advisors check "Buku Mahasiswa" (BKM) and give a signature as a proof of a monitor minimally twice in a semester (at the middle and at the end of the semester). As a control books, it can help the students to check what they are already achieved and what have been attained yet. Ninthly, academic advisors give such as a warning and an educated punishment to the students who break the academic rules, either oral or written.

Tenthly, Academic advisors extend a consideration about the students who want to furlough their study or drop out. Eleventh, Academic advisor must convey the report writingly about the work realization to the dean of faculty every last of semester based on their occupation program. And the last roles of academic advisor are the lecturers who are pointed as academic advisor that is certificated must report their work implementation. Not only, to the dean of faculty but also to the BKD (Beban Kerja Dosen) in every semester.

(Pedoman Edukasi Universitas Islam Negeri Alauddin Makassar, 2013).

\section{The Characteristics of a Good Advisor}

The effectiveness of the roles of academic advisor can be intentioned from the characteristic of the good advisor. According to (Metz and Allan, 1981:10) as academic advisors who responsible to their advisee, they have to possess a good character, how to be a good academic advisor they are: first, academic advisor are personally and professionally interested in being an advisor. Second,Listens constructively, attempting to hear all aspects of students' expressed problems. Third, Sets aside enough regularly scheduled time adequately meet the advising needs of students assigned to him/her advisee. The good advisor should arrange their time appropriately to do academic advising better.

Fourth, the academic advisor must know every single thing about the university policy and practice in sufficient detail to provide students with accurate, usable information. Fifth, academic advisor have to refer student to other sources of information and assistance when referral seems to be the best student-centered response to be made. Either guidance or motivating students, academic advisor should share as many as information that relates to the students learning achievement. Sixth, academic advisor attempts to understand student concerns from a student point of view. Seventh, academic advisor Views long-range planning as well 
as immediate problem-solving as an essential part of effective advising.Ninth, academic advisor continually attempts to improve both the style and substance of his advising role. As the students target can be achieved, the academic advisors always consider and pay attention to the substantial of their advising. Tenth, Willingly and actively participates in advisor-training programs, both initial and in service.

\section{Motivation}

Jane S Halonen \& JhonW.Santrock (1999) stated motivation is the factors that help explain way people behave, think, and feel the way they do (Jane $\mathrm{S}$ Halonen\&JhonW.Santrock,1999:35). On the other words, the researcher mention that motives is such a specific force that energizes and directs behavior toward solving a problem or achieving a goal. Motivation also can we say like self-esteem. Self-esteem is what you feel about yourself. Sardiman portrays motivation is adopting from "motive". This word is determined by the drive or the encouragement naturally appeared to execute something. "Motive" can be also described as the locomotion that appears from inside the people to carry on their activity in order to achieve the target (Sardiman, 1994: 73).

Douglas Brown (2007) defines motivation is the anticipation of reward, whether internally or externally administered, choices made about goals to pursue and the effort exerted in their completion (H. Douglas Brown, 2007:386). As Mc Donald states that motivation is the change of energy that occurs in a person that is characterized by appearing a sense of feeling, it will be preceded by the goal. There are three essential points about motivation that must be considered: Motivation can change people by itself, Motivation appears because of the sense of feeling, and motivation is stimulated by the existing of the target (Sardiman, 1994: 74).

Deborah Sardo-Brown, dkk (2003) portrayed that the motivation is applied when a person is energized to satisfy some need or desire. The person will engaged in, or be attracted toward, activities that are perceive that having the potential to meet this need and desire (Deborah Sardo-Brown, dkk., 2003: 276).

Motivation are including in two parts. First, Motivation is appeared from where it exists. Second, motivation is appeared from where have been learned.

a. Innate motivation

This motivation emerge by itself, it can be produced naturally without learning it though. For instance, the drive of eating, the drive of drinking, and so forth. Frandsen called it as a physiological drives. (Sardiman,1994: 73).

b. Motivation is appeared from what have been learned

This motivation is molded because of the primary learning. For instance, the drive to learn science, social, and so forth. It means that motivation can be obtained 
after learning something. Beside, Frandsen in Sardiman's book stated that this motivation is mentioned as an affiliative need. That proves from the ability to build a good relationship or social relationship. (Sardiman,1994: 84).

\section{The Kinds of Motivation}

\section{a. Intrinsic Motivation}

Sardiman (1994) states intrinsic motivation is the motives that are appeared actively without any stimulation from outside. The intrinsic component is always proponed by the necessary and drive (Sardiman, 1994: 89). Robert N. Singer (1975) defines intrinsic motivation is the origin of a drive within a person, or it can be analyzed as something is done for its own sake (Robert N. Singer, 1975:403).

\section{b. Extrinsic Motivation}

Deborah Sardo-Brown (2003) stated that extrinsic motivation is operative when an individual is motivated by an outcome that is external or somehow related to the activity in which she or he engaged (Deborah Sardo-Brown, 2003: 279). In another words the researcher conclude that extrinsic motivation can be said as the motives that are aroused from outside.

\section{The Theories of Motivation}

There are many theories of motivation, there only a few that can be relevant and valuable in this research. Before settling on one theory to use, the thing that the researcher wants to inform that motivational theories include two main groups, they are content theories and process theories. (Shannon Riley, 2005:2). There are three theories that contribute to the motivation. First, Maslows' Hierarchy of Needs Theory (1954). This theory also explains the individual needs that have to be fulfilled by the individual. Second, McClelland's Needs Theory (1961) McClelland's Need Theory shows the ideas into three types of "needs" that one will acquire over their lifetime as a result of the experiences in their careers or in their personal lives (Schermerhom, 2003:4). This theory refers to the understanding of human behavior and how an individual can be motivated by starring at their needs and inclinations. Third, Herzberg's Two-Factor Theory (1959)

This theory explains two kinds of factors known as the motivation factors and hygiene factors. According to Frederick Herzberg, the motivating factors consist of achievement, recognition, work itself, responsibility, advancement, and possibility of growth; the researcher categorizes this factor into intrinsic motivation. Whereas, Hygiene factors include relationship with the subordinate, personal life and so forth. The researcher categorized it as an extrinsic motivation. 
Ahmiranil Khairat, The Roles of Academic Advisor To The Learming Motivation ...

\section{Learning Motivation}

Learning motivation is a psychology factor that is non-intellectual, the role of this aspect of learning is to boost desire, interested in learning and spirit to run for their daily academic. William Burton in Oemar Malik's book states the motivation is provided by an environment or an educator to stimulate student study hard and work well.

Sunaryo (2009) cited in Tri Sunarsih thesis "Hubungan Antara Motivasi Belajar, Kemandirian Belajar dan Bimbingan Akademik Terbadap Prestasi belajar Mahasiswa STIKES A.Yani Yogyakarta" There are various ways how to make mold the students learning motivation. They are:

a. Motivating by force

This kind of motivation is executed by using a threat, a punishment, and a reward.

This violence will give a big impact to boost students learning motivation; they will do everything they want to do because of the punishment.

b. Motivating by enticement

This way is applied for the compliment or a present to the student, the lecturer or the teacher will give such a compliment, feedback, and a gift by hoping that they can gain their target.

c. Motivating by identification

This motivation can be implanted to the students as realization that the selfconfidence appear from inside the students to attain their target by using their own way.

\section{RESEARCH METHOD}

This research applied descriptive quantitative by doing survey. The function of job analysis survey is to collect the information about the data, the responsible of the people in institution, the facility, and the work condition.

The research design of this research is:

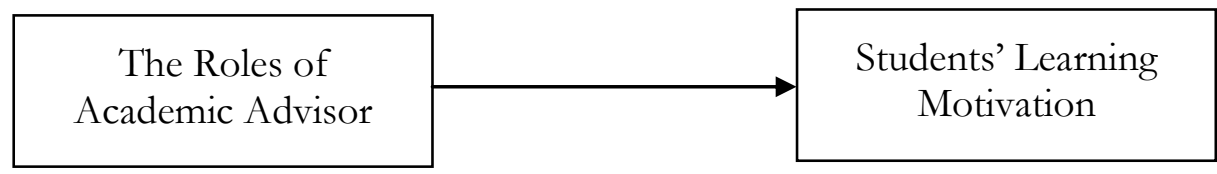

This research consists of two variables. The role of academic advisor as an independent variable or free variable and students learning motivation is dependent variables. The population of this research is the seventh semester students' of 
English Education Department of UIN Alauddin for 2014/2015 academic year. The sample was selected to PBI $3 / 4$ by taking clustered random sampling. The instrument of this research was Questionnaire. For gaining a data, this research conducted direct quisionare. Direct questionnaire is the respondence answer about theirselves. Direct quisionnaire is implemented to measure the roles of academic advisor and students' learning motivation.

The blueprints of this research instrument, they are:

1. The roles of academic advisor variables or independent variable are arranged based on the Pedoman Edukasi Universitas Islam Negeri Alauddin Makassar (2013).

2. Student's learning motivation variables are arranged based on the Herzberg Theory (intrinsic and extrinsic motivation).

The scores of each item is identifying by using likert scale:

Answer Scoring for Each Item

\begin{tabular}{|c|l|c|c|}
\hline No & \multicolumn{1}{|c|}{ Answer Choices } & Favorable Score & Unfavorable Score \\
\hline 1. & Sangat Setuju (SS) & 4 & 1 \\
2. & Setuju (S) & 3 & 2 \\
3. & Tidak setuju (TS) & 2 & 3 \\
4. & Sangat Tidak Setuju (STS) & 1 & 4 \\
\hline
\end{tabular}

The Indicators of Question Items

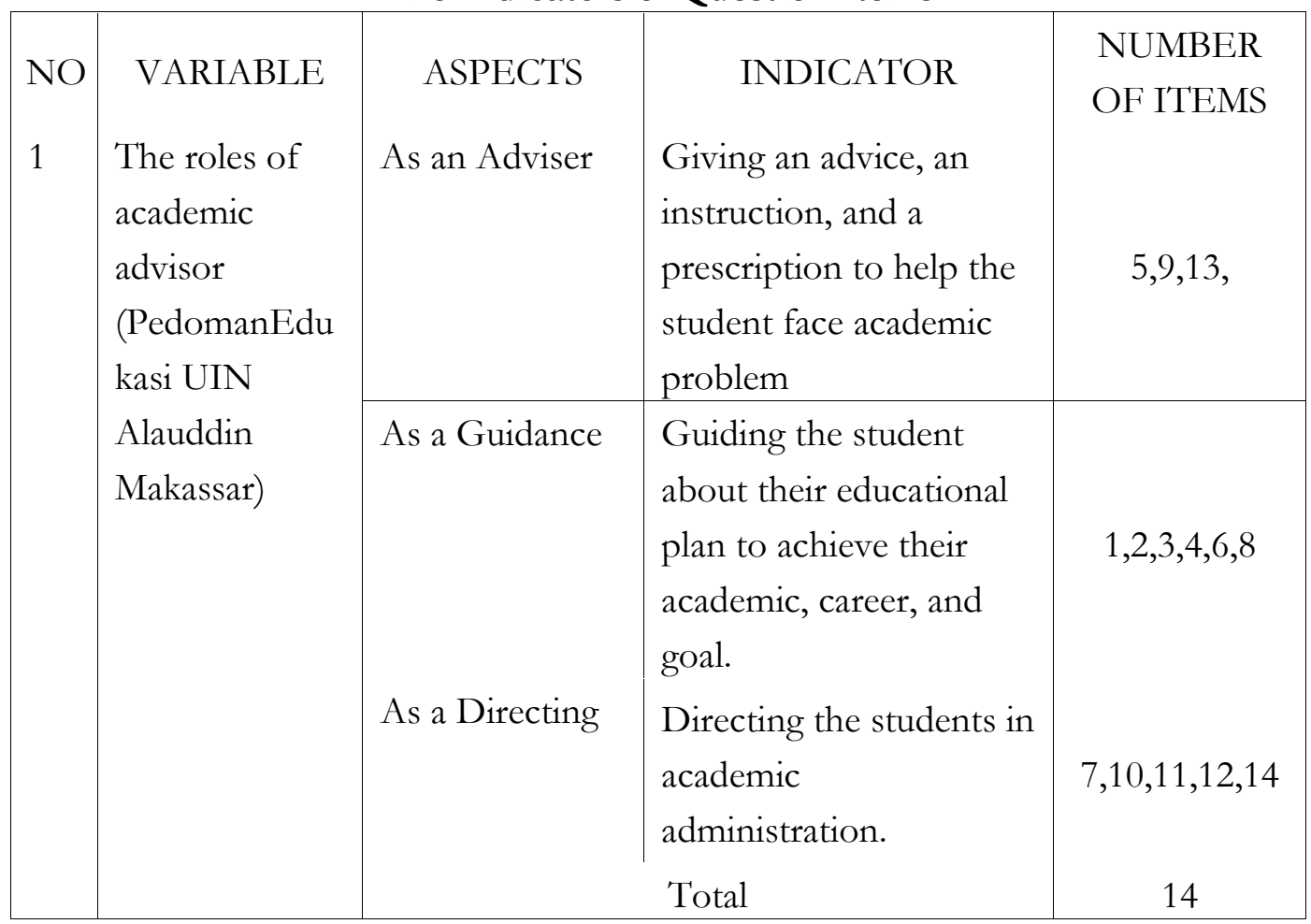


Ahmiranil Khairat, The Roles of Academic Advisor To The Learning Motivation ...

\begin{tabular}{|l|l|l|l|c|}
\hline 2 & $\begin{array}{l}\text { Learning } \\
\text { Motivation } \\
\text { (Hezrberg }\end{array}$ & $\begin{array}{l}\text { Intrinsic } \\
\text { Theory) }\end{array}$ & $\begin{array}{l}\text { An encouragement for } \\
\text { learning }\end{array}$ & $3,6,9$, \\
\cline { 3 - 5 } & \multirow{2}{*}{$\begin{array}{l}\text { Extrinsic } \\
\text { Motivation }\end{array}$} & $\begin{array}{l}\text { The desire in achieving } \\
\text { their academic goals }\end{array}$ & $\begin{array}{l}\text { An Effective learning } \\
\text { process }\end{array}$ & $1,7,12$, \\
\cline { 3 - 5 } & $\begin{array}{l}\text { The Drive to obtain a } \\
\text { highest score }\end{array}$ & $2,11,13,14$ \\
\cline { 3 - 5 } & & Total & 14 \\
\hline
\end{tabular}

The technique of data analysis of this research is consisted of two types descriptive statistic and differential statistic

In descriptive statistic, there are five steps. They are:

1. This step answers the roles of academic advisor to the student learning motivation

a. Obtaining the range

$$
\mathrm{R}=\mathrm{Xt}-\mathrm{Xr}
$$

Where:

$\mathrm{R}=$ The Range is seeked for

$\mathrm{Xt}=$ The Highest Score

$\mathrm{Xr} \quad=$ The Lowest Score

b. Obtaining the Number of Interval Class

$\mathrm{K}=1+3,3 \log \mathrm{N}$ (Sturges)

(Sugiyono, 2012: 37)

Where:

$\mathrm{K}=$ Total Class

$\mathrm{N}=$ Many of Population

c. Counting an interval class

$\mathrm{i}=K$ (Sugiyono, 2012: 33)

Where:

$\mathrm{i}=$ Class Interval

$\mathrm{R} \quad=$ Range

$\mathrm{K}=$ Total Class

d. Mean Score

Calculate the mean score of students by using the formula.

$$
\bar{X}=\frac{\sum \mathrm{X}}{\mathrm{N}}
$$


Where:

$\bar{X}$ : Mean score

$\sum X$ : Sum of all scores

$\mathrm{N}$ : Total number of subject.

e. This step will answer the motivation of students' learning motivation at the seventh semester of English Education Department at Islamic state university of Makassar.

1) Percentage

$\mathrm{P}=\frac{\mathrm{f}}{\mathrm{N}} \times 100 \%$

Where :

P : Number of Percentage

$F$ : Frequency

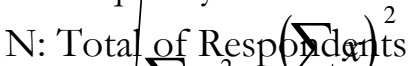

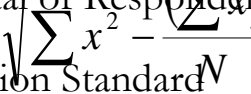

2) Deviation Standar

(Sugiyono, 2012: 58)

Where:

$\mathrm{SD}=$ Deviation Standard

$\mathrm{X}^{2} \quad=$ Kuadrat total score

$\mathrm{N} \quad=$ Population

\section{Inferensial Statistic}

This step will use to answer the roles of academic advisor to the students' learning motivation. They are:

a) Product Moment Correlation

$$
\begin{aligned}
& r_{x y}=\frac{N \sum X Y-\left(\sum X\right)\left(\sum Y\right)}{\sqrt{\left\{N \sum X^{2}-\left(\sum X^{2}\right)\right\}\left\{N \sum Y^{2}-\left(\sum Y^{2}\right)\right\}}} \\
& \text { Where: } \\
& \mathrm{x}=\mathrm{X}-\mathrm{Y} \\
& \mathrm{y}=\mathrm{Y}-\mathrm{X} \\
& \mathrm{X}=\text { The average score from } \mathrm{X} \\
& \mathrm{Y}=\text { The average score from } \mathrm{Y}
\end{aligned}
$$$$
\text { (Sugiyono, 2014:213) }
$$

b) To verify the significance by using T-test and T- Table

$$
t_{\text {hitung }}=\frac{r \sqrt{n-2}}{\sqrt{1-r^{2}}}
$$

Kaidah pengujian :

$$
\begin{aligned}
& \text { Jikat }_{\text {hitung }} \geq \text { darit }_{\text {tabel }} \text {, maka Ho ditolak) } \\
& \text { Jikat }_{\text {hitung }} \leq \text { darit }_{\text {tabel }}, \text { maka Ho diterima) }
\end{aligned}
$$




\section{D.FINDINGS AND DISCUSSION}

\section{The findings of the roles of academic advisors}

Table 2.7

The Category of the Roles of Academic Advisor at the Seventh Semester Students of English Education Department at Alauddin State Islamic University.

\begin{tabular}{|r|c|c|c|c|}
\hline No & Category & Nilai & Frekuensi & Percentage (\%) \\
\hline 1 & High & $37-48$ & 4 & $11.2 \%$ \\
\hline 2 & Medium & $26-36$ & 17 & $47.5 \%$ \\
\hline 3 & Low & $14-25$ & 15 & $41.9 \%$ \\
\hline \multicolumn{3}{|c|}{ Total } & 36 & 100 \\
\hline
\end{tabular}

(SaifuddinAzwar, 2014: 146)

This table categorized is the result of the questionnaire of the roles of academic advisor, the frequency and the percentage. According to the table above, from 36 students as a respondents to cognize the roles of academic advisor at the seventh semester students at Alauddin Islamic State University, it can be known that there are 4 students $(11,2 \%)$ are at the high category, 17 students $(47,5 \%)$ are at the medium category and 15 students $(41,9 \%)$ are at the low category. Based on the mean score that the researcher found 26,92 it means that the roles of academic advisor at the seventh semester students are in the medium category because the distances are about $26-36$. From the explanation above, the researcher concluded that the roles of academic advisor at the seventh semester students at Alauddin State Islamic University of Makassar are in the medium category.

The results of students' learning motivation

Table 2.

The Categorization Table

\begin{tabular}{|c|c|c|c|c|}
\hline No & Category & Score & Frequency & Persentase $(\%)$ \\
\hline 1 & High & $36-45$ & 8 & $22,3 \%$ \\
\hline 2 & Medium & $26-35$ & 15 & $41,7 \%$ \\
\hline 3 & Low & $16-25$ & 13 & $36,3 \%$ \\
\hline \multicolumn{3}{|c|}{ Total } & 36 & 100 \\
\hline
\end{tabular}

According to the table above, it portrayed that 8 students $(22,3 \%)$ are in the high category, 15 students $(41,7 \%)$ are in the medium category, and 14 students 
$(48,3 \%)$ are in the low category. The researcher related it to the mean score 27,75 , if the score is inverted to $26-35$ it means medium category.

Thus, the researcher concluded that the students learning motivation at the seventh semester students at Alauddin State Islamic University of Makassar are in the medium category.

The result of the impact of the roles of academic advisor to the students' learning motivation

Briefly the researcher identified the correlation between two variables based on Ho and Ha. Ho means there is no the correlation between the roles of academic advisors and the students' learning motivation at the seventh semester student of English Education Department in Alauddin State Islamic University of Makassar. Whereas, Ha means there is the correlation between the roles of academic advisors to the students' learning motivation at the seventh semester student of English Education Department in Alauddin State Islamic University of Makassar. It can briefly be written as: Ha: $r \neq 0$ Ho: $r=0$

By using $\alpha=0,05$ and one tail test with Derajat Kebebasan $(\mathrm{dk})=\mathrm{n}-2=36-$ $2=34$, then it is obtained $\mathrm{T}$ table $=1,697$ This $\mathrm{T}$ table can be found on the Table 2 in (Sugiyono, 2012: 372). From this case, the data finally found thatt $t_{\text {hitung }}$ is bigger than $\mathrm{t}_{\text {tabel }}$ or $9,4575 \geq 1,697$, it analyzed that there was a significant correlation between the roles of academic advisor to the students' learning motivation at the seventh semester students of English Education Department in Alauddin State Islamic University of Makassar.

The big influence of $\mathrm{X}$ variables to the $\mathrm{Y}$ variables can be proved from the result of this counting below.

$$
\begin{aligned}
\mathrm{KP} & =\mathrm{r}^{2} \times 100 \% \\
& =0871 \times 100 \% \\
& =0,758641 \times 100 \% \\
& =75,8641 \%
\end{aligned}
$$

From the result above, it can be seen that the contribution of the roles of academic advisor to the students learning motivation at the seventh semester students in Alauddin State Islamic University of Makassar is 75,8641 \%.

From the result of the data analysis above, the data was found there were a significantly correlation between the roles of academic advisors to the students' learning motivation at the seventh semester students of English Education Department in Alauddin State Islamic University of Makassar. It can be determined from the result of product moment correlation is in the high category that indicated that the roles of academic advisor to the students' learning motivation at the seventh semester students of English Education Department in Alauddin State Islamic 
Ahmiranil Khairat, The Roles of Academic Advisor To The Learming Motivation ...

University of Makassar is completely under circumstances or completely have a tightly correlation. According to Pedoman Edukasi UIN Alauddin, based on the researcher's references, it is found that the roles of academic advisor have significantly executed their duty in an appropriate way.

It can be proven by the result of this research. Before conducting this research the researcher accumulated that it would be there is no significantly correlation between the roles of academic advisor to the students' learning motivation. That was similar to the result of the research that was conducted by Aksan (2014), the results examined that the roles of academic advisor were implemented poorly by the academic advisor. But, the fact is not in proper way. This case made the researcher analyzed deeply. It is proven also by the result of unstructured interview from the students as a representative from the class.

She said that there were definite activities that the academic advisor executed when they were doing their academic advising activity. For instance, they always told them their experiences what the academic advisor have been acknowledged about their academic carrier. Academic advisor did the specific creativity that had not written on the (Pedoman Edukasi UIN Alauddin, 2013).

Besides, the students were always guided how to run for their academic activity not only by meeting up but also via mobile phone or social media. This was the researcher can categorized as the academic advisor's creativity in doing academic advising activity. This tightly correlated with the concept of academic advising which declared by NACADA (2014). The successful of academic advising can be identified from the way the academic advisor set the concept of academic advising up. The concept of academic advising from NACADA was equally with the concept of the academic advisor in English Education Department. It can be seen from the result of unstructured interview between students and academic advisor. Besides, the characteristic of academic advisor is more essential that should be considered. According to Metz and Allan, academic advisor have to posses the good character (Metz \& Alan, 1981:10).

From the unstructured interview as a representative from the respondents he said that every meeting that they executed is always in a group. Before conducting their academic advising activity, the academic advisor always gave them such a grammar test though before sharing, giving, and telling motivation, guidance, and instruction from the academic advisor in gaining their learning achievement.

The data descriptive above is also supported by the result of unstructured interview from the academic advisor. He said that as briefly "before doing an academic advising he gathered the students and gave them learning motivation, what 
is the goal of life, what they will do to gain their learning achievement and so forth". Besides, he always told them to create their future carrier and always encourage the students to build the good relationship with many people in every circumstance.

\section{E. CONCLUSION}

The result of this study showed the roles of academic advisor that had been achieved from the seventh semester students' of English Education Department is there are 4 students $(11.2 \%)$ are at the high category, 17 students $(47,5 \%)$ are at the medium category and 15 students $(41,9 \%)$ are at the low category. Based on the mean score of the researcher found 26.92 means that in the medium category because the distances are about 26 - 36. The student's learning motivation at the seventh semester students of English Education Department at Alauddin State Islamic University of Makassar is required by the result of the answers from the respondents. These are the result of the students' learning motivation, there are 8 students $(22,3 \%)$ are in the high category, 15 students are in the medium category $(41,7 \%)$ and there are 14 students are in the low category $(48,3 \%)$. If the researcher compared it to the mean score that is inverted to $26-35$ means in the medium category. The impact of the roles of academic advisor to the students' learning motivation at the seventh semester students of English Education Department at Alauddin State Islamic University of Makassar are in the high category. That can be seen from the result how big the contribution of the roles of academic advisor to students learning motivation is about $75,8641 \%$ the rest of it, it is about $24,1359 \%$ it does not exist in this research.

\section{F. RECOMENDATION}

According to academic advising in English education department, the researcher encourage to the students have to be more active in sharing, communicating, and incorporating related to their academic activity to the academic advisor in order that to enhance their learning motivation in finishing their study. The researcher also suggested the academic advisors to mold an appropriate timing, placing, and educational background of the academic advisor are most essential then anything. The researcher hopes that the lecturers who are occupied as an academic advisor should be from psychological major. Besides, there will be a meeting up schedule once a month or even twice a month. The academic advising can be conducted regularly in a specific room to run for academic advising activity conductively. Besides, the researcher also encourages to the institution as generally 
Ahmiranil Khairat, The Roles of Academic Advisor To The Learming Motivation ...

shaping the innovation of standard operational procedure of academic advisor. It will be better if it is changed or innovated by the time it is needed. The most essential is there is a tightly regulation in conducting academic advising, in order that the academic advisors are more responsible to their duty.

\section{REFERENCES}

Arikunto, S. Prosedur Penelitian. Jakarta: Rineka Cipta, 2010.

Azwar, Saifuddin. Penyusunan Skala Psikologi Yogyakarta: Pustaka Pelajar, 2014.

Aksan, Muhammad. "Hubungan Kinerja Penasehat Akademik Dengan Motivasi Belajar Mahasiswa Mahasiswa di Jurusan Pendidikan Biologi Fakultas Tarbiyah dan Keguruan Universitas Islam Negeri Makassar". Skripsi. Makassar: Fakultas Tarbiyah dan Keguruan UIN Alauddin, 2014.

Brown H. Douglas. Principles of Language Learning and Teaching.Newyork: Pearson Education, 2008.

Brown, Sardo-Deborah, dkk . Educational Pscychology. Singapore: See Lee Press. 2003.

Crockett, David S. "Academic Advising: A Cornerstone of Student Retention." In Reducing the DropoutRate.Edited by Lee Noel. Washington, D.C.: Jossey-Bass, Publishers, 1987.

Crockett, David S., ed. Academic Advising: A Resource Document. Iowa City, Iowa: The American College Testing Program, 1987.

Egan. D Kevin, Drexel University (2014). The Mentor an Academic Advising Journal. Retrieved from:http://dus.psu.edu/mentor/2014/07/empowerment-throughadvising/ (29 Oktober 2014).

Ford, Jerry. "Example University, Academic Advising Handbook”.'Houston: Texas 77036.

Gay. L. R. Educational Research, Competencies for Analysis \& Application. Florida: Charles E Merrill Publishing Company, 2010.

Gordon. Academic Advisor Handbook. The United State: Minot State University Press, 2008.

Hafiduddin dan Nurhasyim. "Peran Pembimbing Akademik Dalam Mengoptimalkan Hasil Studi Mahasiswa : Studi Pada Politeknik Negeri Jakarta” Skripsi. Jakarta: Jurusan Akuntansi Politeknik Negeri Jakarta, 2010.

Hamalik, Oemar . Psikologi belajar \& mengajar. Bandung: Sinar Baru Algesindo, 2010.

Hasbullah . Dasar-Dasar Pendidikan. Jakarta: Raja Grafindo Persada, 2009. 
Hardee, Melvene Draheim, and Mayhew, Lewis B. Faculty Advising in Colleges and Universities. Student personel Series Number 9. Washington, D.C. : American College Personnel Association, 1970.

Jane S. Halonen \& Jhon W. Santrock. Psychology Context \& Applications $3^{\text {rd }}$ Edition. USA: McGraw-Hill, 1999.

Latief, Muhammad Adnan. Research Method on Language Learning an Introduction. Malang: UM Press, 2014.

Metz and Allan. Academic Advising Handbook. Example University: Houston: Texas, 1981.

Pargett K. Kelly, University of Nebraska. The effects of Academic Advising on College Student Development in Higher Education. Retrieved from: bttp:// digitalcommons.unl.edu/cehsedaddiss/81.Pdf, 2010.

Pedoman Edukasi Universitas Islam Negeri Alauddin Makassar. Makassar : UIN, 2013.

Pedoman Penulisan Karya Tulis Ilmiah Universitas Islam Negeri Alauddin Makassar. Makassar: Alauddin Press, 2014.

Peraturan Akademik Universitas Hasanuddin. Makassar: UNHAS,2010.

Peraturan Akademik Universitas Negeri Gorontalo. Gorontalo: UNG, 2012.

Pizzalato, J. E. Advisor, teacher, and partner: Using the learning partnership mode to reshape academic advising. About Campus, 2008.

Riley, Shannon. 2005. Herzber's Two-Factor Theory Of Motivation Applied to the Motivational Techniques withing Financial Institutions". Thesis, Digital Common: Faculty of Business Management, Easter Michigan University, 2005.

Sardiman A.M. Interaksi dan Motivasi Belajar Mengajar. Jakarta: Raja Grafindo Persada, 1994.

Sugiyono. Statistika Untuk Penelitian. Bandung: Alfa Beta, 2012.

Sunarsih, Tri. "Hubungan Antara Motivasi Belajar, Kemandirian Belajar, dan Bimbingan Akademik Terhadap Prestasi Pelajar Mahasiswa di STIKES A.Yani Yogyakarta". Thesis,Yogyakarta: Program Studi Kedokteran Keluarga STIKES A. Yani Yogyakarta, 2009. 